\title{
A NOTE ON THE NESTING HABITS OF TACHYTES DISTINCTUS Sm.
}

By Phil Rau.

\section{St. Louis, Missouri}

A bank at Creve Coeur Lake, composed of sand and soil, contained in a space of six by twelve feet, five nests of this species, on August 16, 1922. All of these domiciles had been established in burrows or openings made by other creatures or objects. Two nests were within the burrows made by rodents, one in an opening left in the soil by a disintegrating root, one in a crack in the bank, and the last in an opening made by a half buried sheet of tin. The mother wasp in each case gained access to her nest by these openings, which were unmodified and quite inconspicuous.

A careful study of these mothers revealed that it is the habit of these wasps to approach the opening by flight, accompanied by a noisy hum that resembles somewhat that of a horse-fly. She drops into her tunnel without preliminary search, or a pause at the doorway, but in a very businesslike manner she plunges in, remains a moment, then flies out and dashes off again. The same quickness characterises her movements, whether she is empty-handed or burdened with prey.

The prey is always a long-horned grasshopper of the species Orchelimum vulgare Harr ${ }^{1}$. It is carried on the under side of her body, held in position by her legs, and despite the fact that its size equals or sometimes exceeds her own, she has no difficulty in managing it, and is not even compelled to readjust it before entering the burrow. She does not experience the difficulty that many wasps do in entering the burrow with a large parcel, since the openings are always large.

The activities of one mother were watched closely, during which time she brought in four grasshoppers after hunts of 65, 55, 32 and 33 minutes respectively, and she took from three to five minutes each time to store them after she entered the burrow.

${ }^{1}$ The wasp was identified by Mr. S. A. Rohwer, and the hopper by Mr. A. N. Caudell. 
An effort was made to excavate the burrows but the sandy soil was friable and in only one was the terminus successfully reached. This was the burrow under the sheet of tin; this sheet lay horizontally about ten inches under the surface of the soil, and by shoveling off this soil the sheet was removed and the tunnel exposed. It was found that her own gallery began about four inches from where she entered the opening beneath the tin. The tunnel ran horizontally and the tin served as its roof, leaving a miniature trench when the sheet was lifted; this trench ran in the shape of a quarter circle for about four inches, where it entered the ground and continued as a straight burrow for an additional distance of six inches, never at any point going down more than $3 / 4$ inch below the plane of the first portion. The diameter of the burrow of her own making was approximately $1 / 2$ inch. One grasshopper was found at the end of the burrow. It lived about a day after its disinterment.

The most interesting feature about the nesting habits of this species is that, though they utilize the old burrows of other creatures, they use them only as a vestibule; but once under cover they dig their own tunnel in a way well becoming to industrious creatures. They do not, like certain other wasps, use ready made burrows for nesting purposes, but only use that site to conceal their nests from prying eyes, where they can work unhindercd. My observations on the habits of this species would be incomplete if I failed to note the very interesting and significant characteristic, its ability to find out and utilize the beginnings of burrows, and thus gain safety and save labor.

Williams (Kans. Univ. Sci. Bull 8:194-197, 1913) finds that the entrance to a burrow of this wasp had a circular mound resembling "somewhat the appearance of a mud tube such as are made by crayfish." May this not actually have been a crayfish burrow that Tachytes used as a vestibule to her own tunnel? Williams also finds in Kansas, that the cells are strung along the main shaft in an irregular manner, and in twenty cells that he opened, fifty six acridians were found. Fifty one of these belonged to the tribe Melanopli, and the other five being Ageneotettix deorum and Orphuella speciosa. 

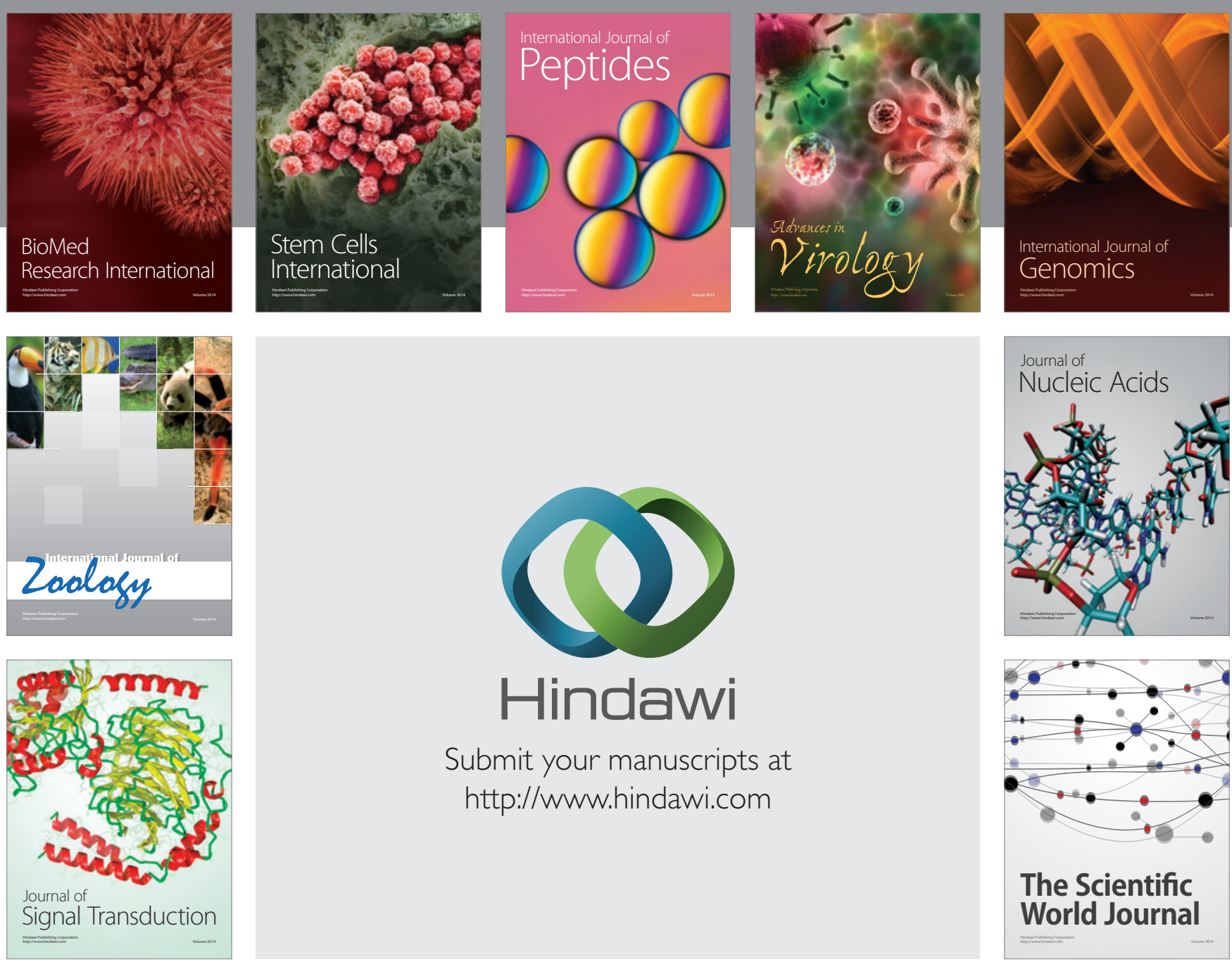

Submit your manuscripts at

http://www.hindawi.com
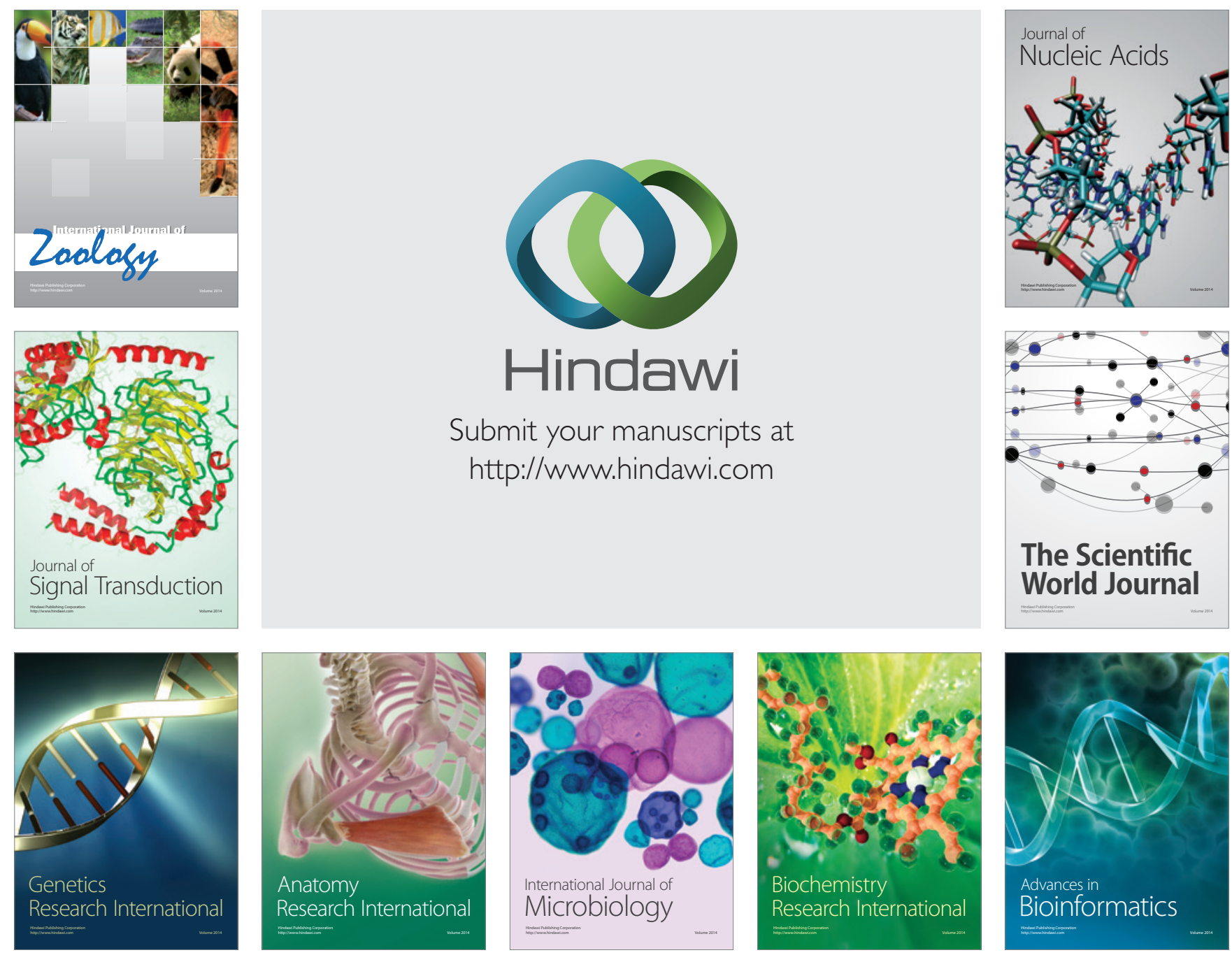

The Scientific World Journal
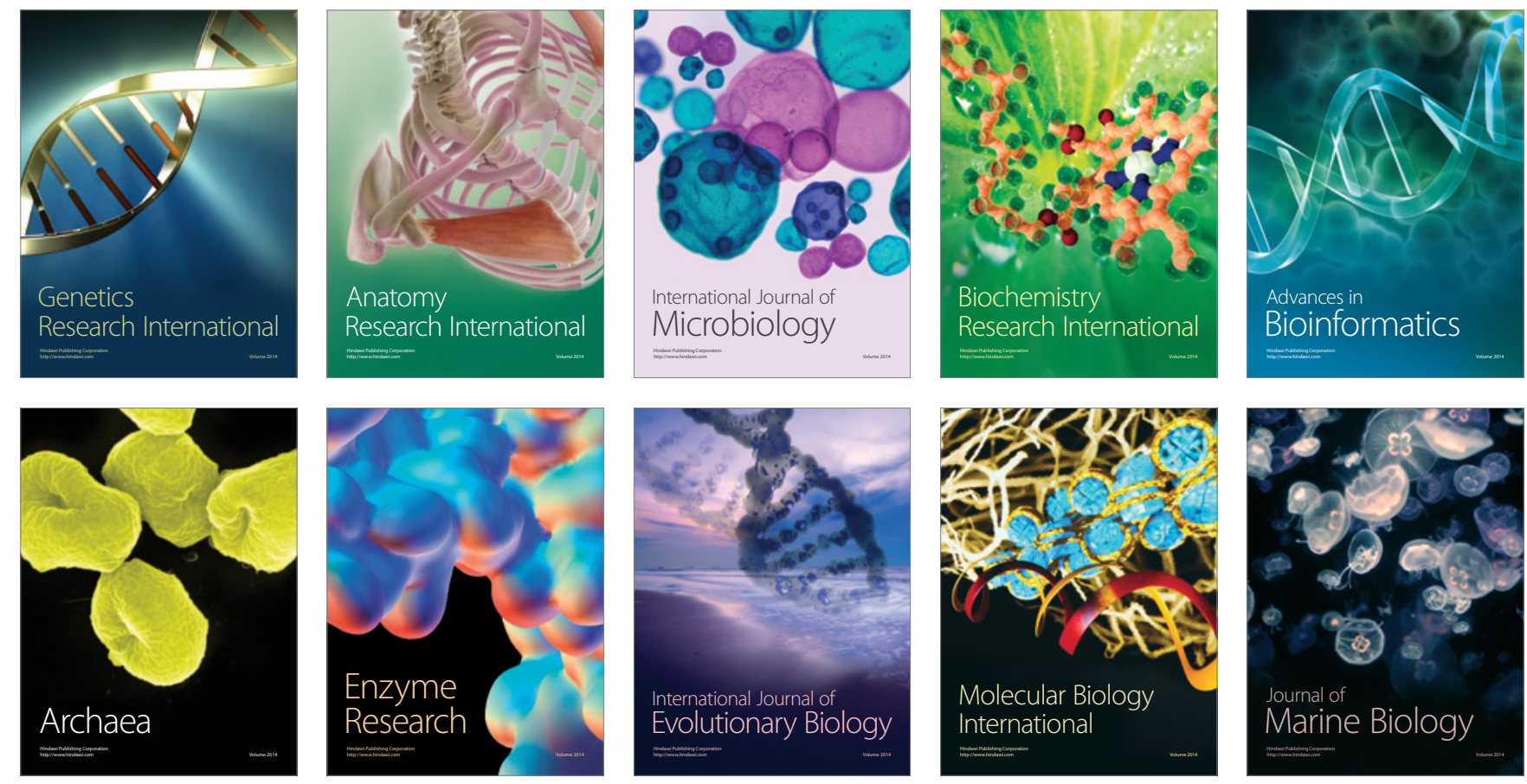